\title{
Giant Papilla Prolapse from the Upper Tarsal Conjunctiva in a 3-year-old Child: A Case Presentation and a Brief Literature Review
}

\author{
Bengi Ece Kurtul, () Suleyman Koca
}

Department of Ophthalmology, Mustafa Kemal University Tayfur Ata Sokmen Faculty of Medicine, Hatay, Turkey

\begin{abstract}
Giant papillae ( $1.0 \mathrm{~mm}$ or greater in diameter) on the upper tarsal conjunctiva are one of the most common findings in cases of vernal keratoconjunctivitis (VKC). Presently described is the case of a 3-year-old female with a unilateral giant papilla formation prolabing from the medial side of the upper tarsal conjunctiva toward the ocular surface in the left eye. A brief review of the recent literature concerning the etiology, associated risk factors, surgical options, and management of patients with giant papillae is also discussed. A significant reduction in the size of the papilla was observed after a week of medical treatment with a topical steroid and antiallergic eye drops. To the best of our knowledge, this case demonstrates the first time that a giant papilla appeared in the form of a prolapsed mass extending from the tarsal conjunctiva in a child with VKC. Ophthalmologists should keep in mind that a giant papilla can look like another form of conjunctival mass, and should not rush to excise or biopsy, as it may respond to medical treatment.
\end{abstract}

Keywords: Conjunctival mass, giant papillae, medical treatment, vernal keratoconjunctivitis

\section{Introduction}

Vernal keratoconjunctivitis (VKC) is a chronic conjunctival inflammatory allergic condition predisposed to atopic disease. Due to its chronic nature, it can damage the cornea, resulting in sight-threatening complications if left untreated. The disease primarily affects young children, starting in the first decade of life (I-5). Giant papillae (1.0 mm or greater in diameter) located on the upper tarsal conjunctiva are one of the most common findings in VKC. Papillae are signs of active inflammation in the palpebral conjunctiva. Treatments of choice for reducing papillae include topical medications (e.g., antihistamines, mast cell stabilizers, corticosteroids, cyclo- sporine A, and tacrolimus) and/or oral medications (e.g., antihistamines and corticosteroids), as well as immunotherapy for recalcitrant cases $(5,6)$. In the event of failure to respond to these medications, supratarsal corticosteroid injection (7-II) and surgery, such as resection (I2-I5), amniotic membrane (I2), mucous membrane $(13,14)$, or autologous conjunctival grafting (15), and carbon dioxide laser application (16) have been reported.

We report the first known instance of a giant papilla appearing in the form of a prolapsed mass extending from the tarsal conjunctiva toward the ocular surface in a child with VKC. The objective is to emphasize that giant papillae may

How to cite this article: Kurtul BE, Koca S. Giant Papilla Prolapse from the Upper Tarsal Conjunctiva in a 3-year-old Child: A Case Presentation and a Brief Literature Review. Beyoglu Eye J 202I; 6(I): 70-73.

Address for correspondence: Bengi Ece Kurtul, MD. Mustafa Kemal Universitesi Tayfur Ata Sokmen Tip Fakultesi, Goz Hastaliklari Anabilim Dali, Hatay, Turkey

Phone: +90 5062358670 E-mail: becekurtul@gmail.com

Submitted Date: October 22, 2020 Accepted Date: January 04, 2021 Available Online Date: February 10, 2021

${ }^{\circ}$ Copyright 2021 by Beyoglu Eye Training and Research Hospital - Available online at www.beyoglueye.com OPEN ACCESS This work is licensed under a Creative Commons Attribution-NonCommercial 4.0 International License. 
mimic another type of conjunctival mass. Dramatic healing of the papilla in this case was seen with topical medical treatment of steroid and antiallergic eye drops without the need for surgery.

\section{Case Report}

A 3-year-old female with an apparent conjunctival mass on the left eye present for I week presented at the clinic. She had no ocular complaints of itching, redness, pain, photophobia, burning, or tearing. An ophthalmological examination revealed a giant papilla formation prolabing from the medial side of the upper tarsal conjunctiva toward the ocular surface in her left eye (Fig. I). It extended downward and slightly covered the corneal surface. Fortunately, the pupillary axis was unaffected. The giant papilla was approximately 4 to $5 \mathrm{~mm}$ in size, smooth, and had a pinkish color. There was also a mild accompanying conjunctival mucous secretion. The inferior tarsal conjunctiva appeared normal. No limbal or corneal involvement was observed. The fundus was normal. Ophthalmic examination of the right eye disclosed no abnormality. She did not have a systemic disease or other atopic manifestations (e.g., asthma or atopic dermatitis) or a relevant family history. There was also no history of trau- ma, contact lens use, ocular prosthesis, or ocular surgery. The refraction was +1.50 D in both eyes. Topical treatment with antiallergic eye drops (olopatadine hydrochloride $0.1 \%$, twice daily), preservative-free tear substitute (polyvinyl alcohol and povidone, 4 times a day), fusidic acid twice a day, and a steroid (loteprednol etabonate $0.5 \%, 3$ times a day) was initiated, with the suspicion that the giant papilla was a sign of VKC. Antihistamine syrup (cetirizine dihydrochloride) once a day was also used. After I week of medical treatment, a marked reduction in papilla size, an approximately 90\% decrease, was observed (Fig. 2). Informed consent was obtained from the patient's parent for publication of this case report.

\section{Discussion}

VKC is a chronic inflammatory disease of the ocular surface and an important type of allergic conjunctival disease. It is frequently observed in young children (especially young boys) with onset usually occurring around the age of 7 years $(I-5)$. The most common signs are giant papillae, superficial keratitis, and conjunctival hyperemia. Patients with VKC frequently have a family or medical history of atopic diseases, such as asthma, rhinitis, or eczema. Complications and re-



Figure I. Prolapsed giant papilla formation on the medial side of the upper tarsal conjunctiva in the left eye of the child.
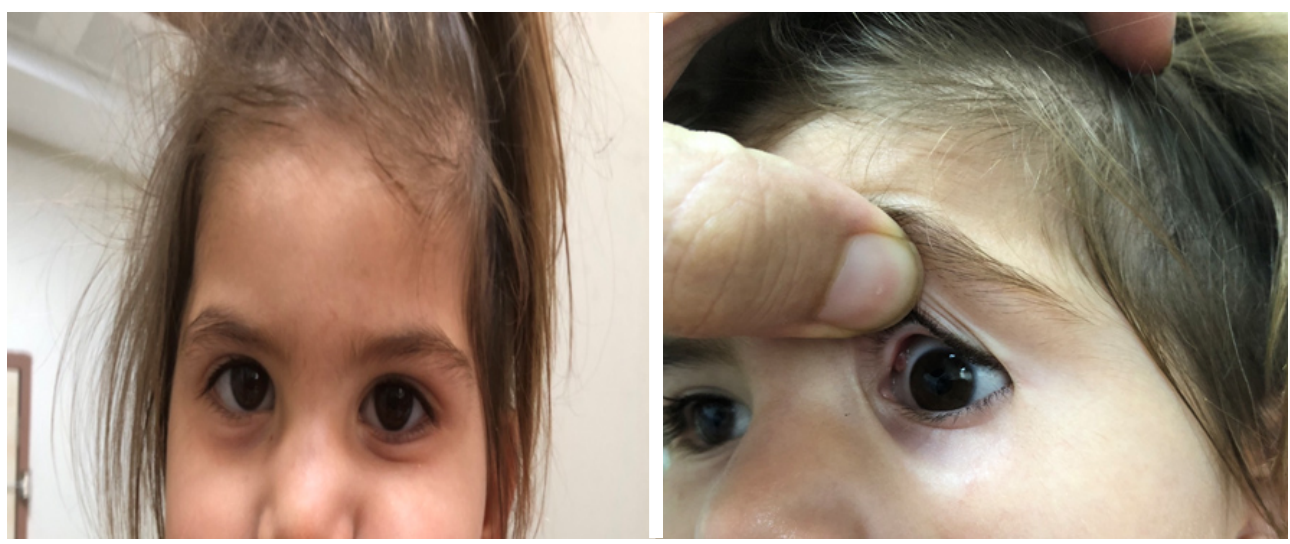

Figure 2. Reduction of the prolapsed giant papilla in the left eye I week after medical treatment. 
modeling changes can lead to blindness in children with VCK; therefore, giant papillae can be a sight-threatening complication $(I-5)$.

Giant papillae are distinguished from follicles by the presence of blood vessels in the center of follicles as well as around the edges. Follicles are more commonly observed in the inferior palpebral conjunctiva and the inferior fornix (4). Papillae are more often seen in the upper palpebral conjunctiva, and are greater than I $\mathrm{mm}$ in diameter and tend to be quite protuberant above the plane of the conjunctival surface, as in our case, whereas follicles are gray-white, creamy, or yellow in color and may be as small as $0.5 \mathrm{~mm}$ in diameter (4). Therefore, the present case was thought to be more likely allergic in origin, rather than infectious. Generally, most VKC cases are bilateral with symmetrical involvement; however, asymmetrical involvement and unilateral cases can occur (I-5). This case had rare unilateral involvement. In addition, the patient was a 3-year-old female, with no history of allergy or ocular complaints such as itching, and the only sign was a giant papilla. Nevertheless, the entire clinical picture made us consider a giant papilla.

Giant papillae may resemble another form of conjunctival mass and can make diagnosis difficult. The differential diagnosis of a pediatric conjunctival mass includes dermolipoma, reactive lymphoid hyperplasia, juvenile xanthogranuloma, extratarsal chalazion, pyogenic granuloma, lymphangioma, hemangioma, hamartoma, histiocytoma, melanoma, rhabdomyosarcoma, epibulbar schwannoma, and choristoma (|7-3I). These tumors are grouped into 2 major categories: congenital and acquired lesions. Acquired lesions are further subdivided based on origin of the mass into surface epithelial, melanocytic, vascular, fibrous, neural, histiocytic, myxoid, myogenic, lipomatous, lymphoid, leukemic, metastatic, and secondary tumors (I7-3I).

In this case of an acquired mass thought to be a giant papilla, conjunctival vascular tumor was the first to be considered in the differential diagnosis. A variety of vascular tumors, including lymphangioma, lymphangiectasia, pyogenic granuloma, infantile capillary hemangioma, and Kaposi's sarcoma, can occur in children at various anatomic locations in the conjunctiva (I7). Vascular tumors tend to occur unilaterally on the bulbar conjunctiva, and the majority are benign (17). Several predisposing factors, such as trauma, surgery, and heredity, can cause conjunctival masses. In our case, the conjunctival mass was unilateral and without any history of risk factors. It originated from the tarsal conjunctiva and healed quickly with topical medical treatment of a steroid and antiallergic eye drops without the need for surgical intervention.

Mild cases of VKC tend to remit with nonspecific and supportive therapy. In contrast, severe cases are usually more protracted with remission/relapse occurring for a prolonged period of time and can include corneal involvement and amblyopia $(4,5)$. In this case report, a giant papilla was covering I to $2 \mathrm{~mm}$ of the superonasal side of the cornea in the primary position. Fortunately, the optic axis was unaffected and there was no marked refraction error.

In conclusion, topical medical treatment with a steroid and antiallergic eye drops can produce a quick recovery from a giant papilla without the need for surgery. While giant papillae can look like a tarsal conjunctival mass in children, ophthalmologists should not rush to perform an excision or biopsy, as it may respond to medical treatment.

\section{Disclosures}

Informed consent: Written, informed consent was obtained from the patient's family for the publication of thís case report and the accompanying images.

Peer-review: Externally peer-reviewed.

Conflict of Interest: None declared.

Authorship Contributions: Involved in design and conduct of the study (BEK); preparation and review of the study (BEK); data collection (BEK, SK).

\section{References}

I. Asada Y, Ebihara N, Funaki T, Yokoi N, Murakami A, Matsuda A. Vernal keratoconjunctivitis with giant papillae on the inferior tarsal conjunctiva. Cornea 2014;33:32-4. [CrossRef]

2. Bonini S, Coassin M, Aronni S, Lambiase A. Vernal keratoconjunctivitis. Eye (Lond) 2004; 18:345-5I. [CrossRef]

3. Vichyanond P, Pacharn P, Pleyer U, Leonardi A. Vernal keratoconjunctivitis: a severe allergic eye disease with remodeling changes. Pediatr Allergy Immunol 2014;25:3 I4-22. [CrossRef]

4. Talero SL, Resnikoff S, Saboyá-Díaz MI, Solomon AW. Giant papillae versus lymphoid follicles of the conjunctiva. Ann Emerg Med 2019;73:694-5. [CrossRef]

5. AlHarkan DH. Management of vernal keratoconjunctivitis in chil- dren in Saudi Arabia. Oman J Ophthalmol 2020;13:3-12.

6. Vichyanond P, Kosrirukvongs $\mathrm{P}$. Use of cyclosporine $\mathrm{A}$ and tacrolimus in treatment of vernal keratoconjunctivitis. Curr Allergy Asthma Rep 2013;13:308-14. [CrossRef]

7. Costa AXD, Gomes JÁP, Marculino LGC, Liendo VL, Barreiro TP, Santos MSD. Supratarsal injection of triamcinolone for severe vernal keratoconjunctivitis in children. Arq Bras Oftalmol 2017;80:186-8. [CrossRef]

8. McSwiney TJ, Power B, Murphy CC, Brosnahan D, Power W. Safety and efficacy of supratarsal triamcinolone for treatment of vernal keratoconjunctivitis in Ireland. Cornea 2019;38:9558. [CrossRef]

9. Zaouali S, Kahloun R, Attia S, Jelliti B, Trigui M, Yahia SB, et al. Supratarsal injection of triamcinolone acetonide and childhood allergic keratoconjunctivitis. Int Ophthalmol 2012;32:99-106.

10. Qamar MR, Latif E, Arain TM, Ullah E. Supratarsal injection of 
triamcinolone for vernal keratoconjunctivitis. Pak J Ophthalmol 2010;26:28-31.

II. Thanathanee O, Bhoomibunchoo C, Suwan-apichon O. Treatment of asymmetrical vernal keratoconjunctivitis with supratarsal corticosteroid injection. BMJ Case Rep 2014;20I4:bcr20I420640I. [CrossRef]

12. Guo P, Kheirkhah A, Zhou WW, Qin L, Shen XL. Surgical resection and amniotic membrane transplantation for treatment of refractory giant papillae in vernal keratoconjunctivitis. Cornea 20।3;32:816-20. [CrossRef]

13. lyer G, Agarwal S, Srinivasan B. Outcomes and rationale of excision and mucous membrane grafting in palpebral vernal keratoconjunctivitis. Cornea 2018;37:172-6. [CrossRef]

14. Tse DT, Mandelbaum S, Epstein E, Baerveldt G. Mucous membrane grafting for severe palpebral vernal conjunctivitis. Arch Ophthalmol 1983;101:1879-83. [CrossRef]

15. Nishiwaki-Dantas MC, Dantas PE, Pezzutti S, Finzi S. Surgical resection of giant papillae and autologous conjunctival graft in patients with severe vernal keratoconjunctivitis and giant papillae. Ophthalmic Plast Reconstr Surg 2000;16:438-42. [CrossRef]

16. Belfair N, Monos T, Levy J, Mnitentag H, Lifshitz T. Removal of giant vernal papillae by $\mathrm{CO} 2$ laser. Can J Ophthalmol 2005;40:472-6. [CrossRef]

17. Shields JA, Mashayekhi A, Kligman BE, Kunz WB, Criss J, Eagle $\mathrm{RC} \mathrm{Jr}$, et al. Vascular tumors of the conjunctiva in 140 cases. Ophthalmology 201 I; I 18:1747-53. [CrossRef]

18. Shields CL, Shields JA. Tumors of the conjunctiva and cornea. Indian J Ophthalmol 2019;67:1930-48. [CrossRef]

19. Akinsola FB, Mbadugha CA, Onakoya AO, Adefule-Ositelu AO, Aribaba OT, Rotimi-Samuel A. Pattern of conjunctival masses seen at Guinness Eye Centre Luth Idi-Araba. Nig Q J Hosp Med 2012;22:39-43.

20. Shields CL, Shields JA. Conjunctival tumors in children. Curr Opin Ophthalmol 2007; 18:35I-60. [CrossRef]
21. Villalón ML, Leal MLÁ, Chávez JR, Santillan EM, Lares-Asseff I, Loera V, et al. Recurrent epibulbar dermoid cyst treated with amniotic membrane implant a case report. BMC Surg 2018;18:98. [CrossRef]

22. Chang M, Park J, Kyung SE. Extratarsal presentation of chalazion. Int Ophthalmol 2017;37:1365-7. [CrossRef]

23. Harkins KA, Perry D, Suh DW. Epibulbar osseous choristoma: A case report. Am J Ophthalmol Case Rep 2016;5:4-6. [CrossRef]

24. Knapp AN, Samara WA, Shields CL, Shields JA, Eagle RC Jr. Conjunctival fibrous histiocytoma in an 8-year-old boy. J AAPOS 2016;20:368-70. [CrossRef]

25. Sarigül Sezenöz A, Karalezli A, Özkan Arat Y, Çoban G, Kiratli $\mathrm{H}$, Terzi A. Metastatic embryonal conjunctival rhabdomyosarcoma in a 4-year-old boy. Ophthalmic Plast Reconstr Surg 2017;33:125-7. [CrossRef]

26. Nair AG, Kaliki S, Mishra DK, Dave TV, Naik MN. Epibulbar schwannoma in a 12-year-old boy: A case report and review of literature. Indian J Ophthalmol 2015;63:620-2. [CrossRef]

27. AlAkeely AG, Alkatan HM, Alsuhaibani AH, AlKhalidi H, Safieh LA, Coupland SE, Edward DP. Benign reactive lymphoid hyperplasia of the conjunctiva in childhood. $\mathrm{Br} \mathrm{J}$ Ophthalmol 2017;101:933-9. [CrossRef]

28. Beykin G, Pe'er J, Amir G, Frenkel S. Paediatric and adolescent elevated conjunctival lesions in the plical area: lymphoma or reactive lymphoid hyperplasia? Br J Ophthalmol 2014;98:645-50.

29. Lee Y, Hyon JY, Jeon HS. Conjunctival pyogenic granuloma: cases with undetermined etiologies. Korean J Ophthalmol 2019;33:483-4. [CrossRef]

30. Okudolo JO, Bagg A, Meghpara BB, Sieber MR, Eagle RC Jr, Milman T. Conjunctival pediatric-type follicular lymphoma. Ophthalmic Plast Reconstr Surg 2020;36:46-9. [CrossRef]

31. DeMaria LN, Silverman NK, Shinder R. Ophthalmic pyogenic granulomas treated with topical timolol-clinical features of 17 cases. Ophthalmic Plast Reconstr Surg 2018;34:579-82. [CrossRef] 